\title{
Antiestrogens upregulate estrogen receptor $\beta$ expression and inhibit adrenocortical H295R cell proliferation
}

\author{
D Montanaro, M Maggiolini, A G Recchia, R Sirianni, S Aquila, L Barzon', F Fallo², \\ S Andò and V Pezzi
}

Departments of Pharmaco-Biology and Cell Biology, University of Calabria, 87036 Arcavacata di Rende (CS), Italy
${ }^{1}$ Department of Histology, Microbiology and Medical Biotechnologies and ${ }^{2}$ Department of Medical and Surgical Sciences, Clinica Medica 3, University of Padova, 35128
Padova, Italy

(Requests for offprints should be addressed to V Pezzi, Department of Pharmaco-Biology, University of Calabria, Arcavacata di Rende (CS) 87036, Italy; Email: v.pezzi@unical.it)

\begin{abstract}
The molecular mechanisms involved in adrenocortical tumorigenesis are still not completely understood. In this study, using the H295R cell line as a model system, we investigated the role of estrogens and estrogen receptor (ER) $\alpha$ and $E R \beta$ in the growth regulation of adrenocortical tumors. We demonstrated that H295R cells are able to convert androgens to estrogens by a constitutive expression of active cytochrome P450 aromatase protein and express ER $\beta$ to a greater extent than $\mathrm{ER} \alpha$. Moreover, physiological concentrations of $17 \beta$-estradiol $\left(\mathrm{E}_{2}\right)$ determined an increase of thymidine incorporation, suggesting the presence of an autocrine mechanism in maintaining H295R cell proliferation. Evaluating the response to ER antagonists like 4-hydroxytamoxifen (OHT) and ICl 182780 (ICl), we observed an up-regulation of ER $\beta$ and a dose-dependent inhibition of H295R cell proliferation. Whereas ICl determined the growth arrest of H295R cells, OHT induced morphological changes that were characteristic of apoptosis. According to the above-mentioned observations, OHT but not ICl clearly induced a marked expression of FasL and the cleavage of both caspase-8 and caspase-3. Interestingly, the apoptotic effects of OHT in H295R cells may be consequent to the enhanced levels of ER $\beta$ which stimulate the expression of FasL interacting with activating protein (AP)- 1 sites located within its promoter sequence. In conclusion, we have demonstrated that H295R cells are able to transform androgens to estrogens that activate an autocrine mechanism, mediated by their own receptors, and contribute to regulate the proliferation of these cells. Moreover, this study points towards a role for ER $\beta$ as an important mediator of the repressive effects exerted by antiestrogens on H295R cells; however, further studies are needed to clarify its role in the control of adrenocortical cell proliferation and on the potential benefits of antiestrogens for treatment of adrenocortical cancer.
\end{abstract}

Journal of Molecular Endocrinology (2005) 35, 245-256

\section{Introduction}

Adrenocortical cancers are highly malignant and associated with a poor prognosis. The molecular mechanisms involved in adrenocortical tumorigenesis are still not completely understood. However, several studies have revealed an alteration of a wide variety of signaling pathways such as the mutation of the tumor-suppressor gene TP53 and ras gene family as well as the up-regulation of the insulin-like growth factor (IGF) II system (Logié et al. 1999, Barzon et al. 2001, Kirschner 2002).

The H295R adrenocortical carcinoma cell line (Rainey et al. 1994) was derived from H295 cells, which were established from a primary hormonally active adrenocortical carcinoma (Gazdar et al. 1990), and has been used as a model system to investigate the role of different signaling pathways in the growth regulation of adrenocortical tumors (Rossi et al. 1998, Logié et al.
1999, Bourcigaux et al. 2000). The IGF system has been well characterized (Weber et al. 2000): the IGF-II but not the IGF-I gene is strongly expressed in H295R cells as well as in human adrenocortical tumors and exhibits paternal isodisomy (loss of the maternal-derived allele and duplication of the IGF-II active paternal allele) or less frequently the loss of imprinting (Gicquel et al. 1997). IGF-II regulates the growth of adrenal cells by binding to the IGF receptor and inducing the activation of kinase systems as well as mitogen-activated protein kinases or protein kinase B/Akt (Kirschner 2002). Recently, in several tumoral cells the presence of a cross-talk has been reported between the IGF system and estrogens, which is able to activate the same pathway through the action of estrogen receptors (ERs; Hamelers \& Steenbergh 2003).

It has been largely demonstrated that the effects of estrogens on target tissues are mediated by the $\mathrm{ER} \alpha$ and $\mathrm{ER} \beta$, which act as transcription factors 
(Nilsson et al. 2001). In the human fetal adrenal gland the mRNA of ER $\beta$ was much more expressed than that of $\mathrm{ER} \alpha$ and the $\mathrm{ER} \beta$ protein was detected in the definitive zone of the adrenal cortex (Takeyama et al. 2001). The highly estrogenic environment during pregnancy has been reported to influence steroidogenesis of the primate fetal gland (Hirst et al. 1992, Albrecht et al. 1999) and it has been suggested that the effects of estrogens via ER $\beta$ may play an important role in modulating the development of both human and primate fetal adrenal glands (Albrecht et al. 1999, Takeyama et al. 2001). However, it remains to be elucidated whether estrogens can influence adrenocortical growth and function in the adult, and even tumorigenesis like that observed in other hormonedependent tissues (Gao et al. 2002). A possible involvement of estrogens in adrenocortical tumor development is suggested by epidemiological and experimental studies. Adrenal tumors, and especially functioning tumors, are more frequently found in women than in men (Barzon et al. 2003). Moreover, adrenocortical cancers show a different distribution among genders, with functioning tumors, which represent about half of adrenocortical carcinomas, significantly more frequent in females, and non-functioning carcinomas more frequent in males. Interestingly, a case-control study demonstrated that use of estro-progestins was a risk-factor for the development of adrenocortical carcinomas (Hsing et al. 1996). Moreover, a recent study on H295R cells (Somjen et al. 2003) has shown that these cells are sensitive to low doses of estrogens in terms of proliferation and that they express mRNA of both ER isoforms.

In the present study, using the H295R cell as a model system, we investigated the involvement of estrogen and ERs in the growth regulation of adrenocortical carcinoma. We have demonstrated that H295R cells are able to transform androgens to estrogens that activate an autocrine mechanism, mediated by their own receptors, and contribute to the regulation of proliferation of these cells. Moreover, for the first time we have revealed that in $\mathrm{H} 295 \mathrm{R}$ cells antiestrogens such as 4-hydroxytamoxifen (OHT) and ICI 182,780 (ICI) exert relevant growth-inhibitory effects through different pathways. For instance, OHT induces apoptosis in H295R cells, up-regulating the expression of FasL and determining the autocrine activation of caspases.

\section{Materials and methods}

\section{Reagents}

Forskolin (FSK), 17 $\beta$-estradiol $\left(\mathrm{E}_{2}\right)$ and OHT were purchased from Sigma (St Louis, MO, USA), ICI was a gift from Astra-Zeneca (Italy) and Letrozole was a gift from Novartis Pharma AG (Basel, Switzerland). All these reagents were dissolved in dimethylsulfoxide (DMSO).

\section{Cell cultures}

H295R cells, a cell line established from a human adrenocortical carcinoma, was obtained from Dr W E Rainey (University of Texas Southwestern Medical Center, Dallas, TX, USA) and cultured in Dulbecco's modified Eagle's medium/Ham's F12 (DMEM/F12; 1:1; Eurobio, Les Ulis, France) supplemented with 1\% ITS Liquid Media Supplement $(100 \times$; Sigma), 10\% calf serum and antibiotics (Eurobio), at $37^{\circ} \mathrm{C}$ in an atmosphere of humidified air containing $5 \% \mathrm{CO}_{2}$. MCF-7 breast cancer cells were incubated in the same conditions but maintained in DMEM/F12 supplemented with 10\% calf serum.

\section{Plasmids and in vitro transcription/translation}

The coding regions of $\mathrm{ER} \alpha$ and $\mathrm{ER} \beta$ were excised from their vector and subcloned into the pcDNA3.1 zeo(+) expression plasmid (Invitrogen, Carlsbad, CA, USA). $1 \mu \mathrm{g}$ each plasmid was used for in vitro transcription/ translation using T7 RNA polymerase in the rabbit reticulocyte system following manufacturer's protocol for the TNT kit (Promega, Madison, WI, USA) in a final volume of $50 \mu \mathrm{l}$.

\section{Aromatase activity assay}

The aromatase activity in subconfluent H295R cell culture medium was measured by tritiated water-release assay using $0.5 \mu \mathrm{M}\left[1 \beta-{ }^{3} \mathrm{H}(\mathrm{N})\right]$ androst-4-ene-3,17-dione (25.3 Ci/mmol; DuPont NEN, Boston, MA, USA) as a substrate (Lephart \& Simpson 1991). Incubations were performed at $37{ }^{\circ} \mathrm{C}$ for $2 \mathrm{~h}$ under a $95 \%: 5 \%$ air $/ \mathrm{CO}_{2}$ atmosphere. The results obtained were expressed as $\mathrm{pmol} / \mathrm{h}$ and normalized to milligram of protein $(\mathrm{pmol} / \mathrm{h}$ per mg protein).

\section{Estradiol measurement}

Subconfluent H295R cells, seeded in 12-well/plates at the concentration of $5 \times 10^{5}$ cells/well, were washed twice with PBS and grown in medium without serum. After $24 \mathrm{~h}$, cells were washed again with PBS and grown in $0.5 \mathrm{ml} /$ well fresh medium without serum for 48 and $72 \mathrm{~h}$. The experiment was performed three times in sextuplicate. Total $\mathrm{E}_{2}$ was measured in the supernatant of H295R cells by competitive immunoassays on ADVIA Centaur (Bayer Diagnostics, Tarrytown, NY, USA).

\section{RNA isolation and reverse transcriptase (RT)-PCR}

Total cellular RNA was extracted from H295R cells with Trizol reagent (Invitrogen, Life Technologies, San Giuliano Milanese, Italy) according to the protocol provided by the manufacturer. All the RNA was 
DNase-treated using the DNA-free $(\mathrm{II})$ kit (Ambion, Austin, TX, USA), and purity and integrity of the RNA was checked spectroscopically and by gel electrophoresis before carrying out the analytical procedures. The evaluation of gene expression was performed by semiquantitative RT-PGR (Maggiolini et al. 1999). For cytochrome P450 aromatase (henceforth called P450 aromatase), ER $\beta$ and internal control gene $36 \mathrm{~B} 4$ the primers were 5'-CTGGAAGAATGTATGGACTT-3' (P450 aromatase forward), 5'-GATCATTTCGAGCAT GTTTT-3' (P450 aromatase reverse), 5'-CAGCATTC CCAGCAATGTCAC-3' (ER $\beta$ forward), 5'-GCAGAA GTGAGCATCGCTCTTTG-3' (ER $\beta$ reverse), 5'-CTC AACATCTCGCGCTTCTC-3' (36B4 forward) and 5'-CAAATCGCATATCGTCGTCG-3' (36B4 reverse), to yield products of 660,281 and $408 \mathrm{bp}$, respectively, with 30, 20 and 15 PCR cycles of $1 \mathrm{~min}$ at $95^{\circ} \mathrm{C}$ for all genes, $1 \mathrm{~min}$ at $64{ }^{\circ} \mathrm{C}$ for $\mathrm{P} 450$ aromatase, $1 \mathrm{~min}$ at $58{ }^{\circ} \mathrm{C}$ for $\mathrm{ER} \beta$ and $1 \mathrm{~min}$ at $57^{\circ} \mathrm{C}$ for $36 \mathrm{~B} 4$, followed by $1 \mathrm{~min}$ at $72{ }^{\circ} \mathrm{C}$ for all genes.

\section{Western-blot analysis}

Total cell protein extracts from H295R and MCF-7 cells were lysed in ice-cold Ripa buffer containing protease inhibitors $(20 \mathrm{mM}$ Tris, $150 \mathrm{mM} \mathrm{NaCl}, 1 \%$ Igepal, $0 \cdot 5 \%$ sodium deoxycholate, $1 \mathrm{mM}$ EDTA, $0 \cdot 1 \%$ SDS, $1 \mathrm{mM}$ PMSF, $0 \cdot 15$ units $/ \mathrm{ml}$ aprotinin and $10 \mu \mathrm{M}$ leupeptin). Nuclear extracts were prepared from H295R and MCF-7 as previously described (Andrews \& Faller 1991). Briefly, cells plated onto $60 \mathrm{~mm}^{2}$ dishes were scraped into $1.5 \mathrm{ml}$ cold PBS. Cells were pelleted for $10 \mathrm{~s}$ and resuspended in $400 \mu \mathrm{l}$ cold buffer $\mathrm{A}$, containing protease inhibitors, $10 \mathrm{mM}$ Hepes, $\mathrm{pH} 7.9,1.5 \mathrm{mM}$ $\mathrm{MgCl}_{2}, 10 \mathrm{mM} \mathrm{KCl}, 0.5 \mathrm{mM}$ dithiothreitol, $0.2 \mathrm{mM}$ PMSF, $10 \mu \mathrm{M}$ leupeptin and $0 \cdot 15$ units $/ \mathrm{ml}$ aprotinin, by flicking the tube. The cells were allowed to swell on ice for $10 \mathrm{~min}$ and then vortexed for $10 \mathrm{~s}$. Samples were centrifuged for $10 \mathrm{~s}$ and the supernatant fraction discarded. The pellet was resuspended in $50 \mu \mathrm{l}$ cold buffer C (20 mM Hepes, pH 7.9, 25\% glycerol, $1.5 \mathrm{mM}$ $\mathrm{MgCl}_{2}, \quad 420 \mathrm{mM}$ NaCl, $0.2 \mathrm{mM}$ EDTA, $0.5 \mathrm{mM}$ dithiothreitol, $0.2 \mathrm{mM}$ PMSF, $10 \mu \mathrm{M}$ leupeptin and 0.15 units $/ \mathrm{ml}$ aprotinin) and incubated on ice for $20 \mathrm{~min}$ for high-salt extraction. Cellular debris was removed by centrifugation for $2 \mathrm{~min}$ at $4{ }^{\circ} \mathrm{C}$ and the supernatant fraction (containing DNA-binding proteins) was stored at $-70{ }^{\circ} \mathrm{C}$. The yield was determined by Bradford method (Bradford 1976). The proteins were separated on 11\% SDS/polyacrylamide gel and then electroblotted onto a nitrocellulose membrane. The blots were incubated overnight at $4{ }^{\circ} \mathrm{C}$ with (1) mouse anti-(human $\mathrm{P} 450$ aromatase) antibody, raised against a conserved epitope within P450 aromatase (1:1000; Serotec, Oxford, UK), (2) anti-ER $\beta$ antibody against the C-terminal region of the ER $\beta$ (1:500; Serotec), (3)
anti-ER $\alpha(\mathrm{F}-10)$ antibody against the N-terminal region of the ER $\alpha$ (1:1000; Santa Cruz Biotechnology, Santa Cruz, CA, USA), (4) anti-caspase-8 1C12 monoclonal antibody (1:1000; Cell Signaling Technology, Celbio, Milan, Italy), (5) anti-caspase-3 antibody (1:1000; Cell Signaling Technology), (6) anti-Fas (FL-335) antibody (1:1000; Santa Cruz Biotechnology) and (7) anti-FasL antibody (1:1000; DB Transduction Laboratories, Lexington, KY, USA). The antigen-antibody complexes were detected by incubation of the membranes at room temperature with goat anti-mouse IgG coupled to peroxidase, developed using the ECL Plus Western-blotting detection system (Amersham Biosciences, Cologno Monzese, Italy). As a loading control, membranes were stripped and reprobed with $\beta$-actin antiserum.

\section{Cell-proliferation assay}

A total of $1 \times 10^{6}$ cells were seeded onto six-well plates in complete medium, for proliferative analysis. After 3 days the medium was replaced with DMEM lacking Phenol Red as well as serum and ITS Liquid Media Supplement and treated with different concentrations of $\mathrm{E}_{2}$, ICI 182780 and OHT alone or in combination for $96 \mathrm{~h}$. Control cells were treated with the same amount of vehicle alone (DMSO) that never exceeded the concentration of $0.01 \%(\mathrm{v} / \mathrm{v})$.

$\left[{ }^{3} \mathrm{H}\right]$ Thymidine incorporation was evaluated after a 24-h incubation period with $1 \mu \mathrm{Ci}\left[{ }^{3} \mathrm{H}\right]$ thymidine (PerkinElmer Life Sciences, Boston, MA, USA) per well. Cells were washed once with $10 \%$ trichloroacetic acid, twice with $5 \%$ trichloroacetic acid and lysed in $1 \mathrm{ml}$ $0 \cdot 1 \mathrm{M} \mathrm{NaOH}$ at $37^{\circ} \mathrm{C}$ for $30 \mathrm{~min}$. The total suspension was added to $10 \mathrm{ml}$ optifluor fluid and was counted in a scintillation counter.

\section{Staining for apoptosis detection}

The apoptotic cells were stained using Hoechst 33342 staining (Sigma). H295R cells, plated on chamber slides, were fixed with $4 \%$ paraformaldehyde and stained with Hoechst 33342 dye to a final concentration of $5 \mu \mathrm{g} / \mathrm{ml}$ $(150 \mu \mathrm{M})$ for $20 \mathrm{~min}$ at room temperature. Following washing with PBS, the cells were observed under an Olympus BX51 fluorescence microscope.

\section{Chromatin immunoprecipitation (ChIP)}

This assay was performed using the ChIP assay kit from Upstate Biotechnology (Lake Placid, NY, USA; http:// www.nature.com/cgi-taf/DynaPage.taf?file = /onc/journal/ v23/n45/full/1208014a.html-bib23\#bib23) with minor modifications in the protocol. H295R cells were grown in $100 \mathrm{~mm}$ plates. Confluent cultures $(90 \%)$ were treated for $24 \mathrm{~h}$ with $10 \mathrm{nM} \mathrm{E}, 10 \mu \mathrm{M}$ OHT or $10 \mu \mathrm{M}$ ICI. Control cells were treated with the same amount of 
vehicle alone (DMSO) that never exceeded $0 \cdot 01 \%(\mathrm{v} / \mathrm{v})$. Following treatment DNA-protein complexes were cross-linked with $1 \%$ formaldehyde at $37^{\circ} \mathrm{C}$ for $10 \mathrm{~min}$. Next, cells were collected and resuspended in $400 \mu \mathrm{l}$ SDS lysis buffer (Upstate Biotechnology) and left on ice for $10 \mathrm{~min}$. Cells were sonicated four times for $10 \mathrm{~s}$ at 30\% maximal power (Vibra Cell VCX 500; Sonics \& Material, Inc. Newtown, CT, USA) and collected by centrifugation at $4{ }^{\circ} \mathrm{C}$ for $10 \mathrm{~min}$ at $11000 \mathrm{~g}$. Of the supernatants $20 \mu \mathrm{l}$ were kept as input (starting material, to normalize results) and $100 \mu \mathrm{l}$ were diluted 1:10 in $900 \mu \mathrm{l} \mathrm{ChIP} \mathrm{dilution} \mathrm{buffer} \mathrm{(Upstate} \mathrm{Biotechnology)} \mathrm{and}$ immunocleared with $80 \mu \mathrm{l}$ sonicated salmon sperm DNA-Protein A agarose (Upstate Biotechnology) for $6 \mathrm{~h}$ at $4{ }^{\circ} \mathrm{C}$. The precleared chromatin was immunoprecipitated overnight with $2 \mu \mathrm{g}$ specific anti-ER $\beta$ antibody. The following day $60 \mu \mathrm{l}$ salmon sperm DNA-Protein A agarose was added and precipitation was continued at $4{ }^{\circ} \mathrm{C}$ until the day after. After pelleting, precipitates were washed sequentially for $5 \mathrm{~min}$ with the following buffers: High Salt Immune Complex Wash Buffer, Low Salt Immune Complex Wash Buffer, LiCl Immune Complex Wash Buffer and then twice with TE buffer (all buffers are contained in the kit). The immune complexes were eluted with elution buffer ( $1 \%$ SDS and $0 \cdot 1 \mathrm{M}$ $\mathrm{NaHCO}_{3}$. The eluates and the $20 \mu \mathrm{l}$ input were reverse cross-linked by heating at $65{ }^{\circ} \mathrm{C}$ overnight and digested with proteinase $\mathrm{K}(0.5 \mathrm{mg} / \mathrm{ml})$ at $45^{\circ} \mathrm{C}$ for $1 \mathrm{~h}$. DNA was recovered by phenol/chloroform extractions. A $2 \mu \mathrm{l}$ aliquot of $10 \mathrm{mg} / \mathrm{ml}$ yeast tRNA was added to each sample and DNA was precipitated with ethanol for $1 \mathrm{~h}$ at $-20{ }^{\circ} \mathrm{C}$ and then resuspended in $50 \mu \mathrm{l}$ TE buffer. A $5 \mu \mathrm{l}$ volume of each sample and $2 \mu \mathrm{l}$ of input were used for PCR using the following FasL promoter primers (GenBank accession no. AF035584): sense, 5'-AAACTG AGGCAGGAGGATGT-3', and antisense, 5'-TCG TAGTTAAGTGGAGCGTC-3'. The PGR conditions were $1 \mathrm{~min}$ at $94^{\circ} \mathrm{C}, 1 \mathrm{~min}$ at $55^{\circ} \mathrm{C}$ and 2 min at $72{ }^{\circ} \mathrm{C}$ for 30 cycles. The amplification products of $200 \mathrm{bp}$ were analyzed on a $1 \%$ agarose gel and visualized by ethidium bromide staining. In control samples, nonimmune rabbit IgG was used instead of the specific antibody.

\section{Statistical analysis}

Statistical analysis was performed using one-way ANOVA. Data were analyzed using software from STATPAC (Minneapolis, MN, USA).

\section{Results}

\section{Estradiol production and aromatase activity in H295R cells}

We initially examined whether H295R cells, used as a model system, were able to synthesize estrogens. H295R cells were cultured for 48 and $72 \mathrm{~h}$ in serum-free medium; $\mathrm{E}_{2}$ content was measured with a competitive immuno assay and revealed a time-dependent increase. $\mathrm{E}_{2}$ medium content was $512 \pm 36 \mathrm{pg} / \mathrm{ml}$ at 48 and $834 \pm 67 \mathrm{pg} / \mathrm{ml}$ at $72 \mathrm{~h}$.

We next investigated the expression and the activity of P450 aromatase in the absence or presence of the adenylate cyclase activator FSK. A 24-h treatment with FSK significantly increased aromatase mRNA expression (Fig. 1A and $\mathrm{B}$ ) and protein levels (Fig. $1 \mathrm{C}$ and $\mathrm{D}$ ). This behavior was reproduced with aromatase activity, which was $7 \cdot 43 \pm 0.4 \mathrm{pmol} / \mathrm{h}$ per $\mathrm{mg}$ protein in basal conditions and increased to $23 \cdot 28 \pm 2 \cdot 5 \mathrm{pmol} / \mathrm{h}$ per $\mathrm{mg}$ protein after incubating cells for $24 \mathrm{~h}$ with FSK. The presence of the aromatase inhibitor Letrozole, used $1 \mathrm{~h}$ before and during the incubation with the tritiated aromatase substrate, inhibited basal and, in particular, FSK-induced aromatase activity to $1 \cdot 087 \pm 0 \cdot 1 \mathrm{pmol} / \mathrm{h}$ per mg protein (Fig. 1E).

\section{Expression of ER $\alpha$ and ER $\beta$ in H295R cells}

Since the effects of estrogens on target tissues are mediated by the estrogen receptors (ER $\alpha$ and $\operatorname{ER} \beta$ ), we next investigated the expression of these factors in H295R cells. We subcloned the ER $\alpha$ and ER $\beta$ genes into the expression vectors pcDNA3.1 zeo(+) and used these vectors for in vitro transcription, and the synthetized proteins were utilized as a standard curve for ER $\alpha$ and ER $\beta$ in Western-blot analysis. Standard points were obtained using increasing amounts of the synthetized proteins $(0 \cdot 5,1,3$ and $6 \mu \mathrm{l})$. Densitometric analysis, reference band intesities to the curve where the standard point with the lowest concentration was taken as $100 \%$, indicated that in H295R cells ER $\beta$ is significantly higher than ER $\alpha$. We also used MCF-7 human breast cancer cells, a known ER $\alpha$-positive cell type, as a control, and found as expected a high expression of the ER $\alpha$ isoform, whereas ER $\beta$ was barely detectable (Fig. 2). Based on these results we focused our attention on the role of $\mathrm{ER} \beta$ in mediating estrogen signaling in this adrenal cancer cell line.

\section{$E_{2}$ enhances while antiestrogens and the aromatase inhibitor Letrozole inhibit the proliferation of H295R cells}

We then aimed to investigate the effects of $\mathrm{E}_{2}$ on the proliferation of $\mathrm{H} 295 \mathrm{R}$ cells assayed using thymidine incorporation. Treatment with different concentrations of $\mathrm{E}_{2}(0 \cdot 1-1000 \mathrm{nM})$ for $96 \mathrm{~h}$ exhibited a slight but significative increase of thymidine incorporation (Fig. $3 \mathrm{~A})$, while shorter exposures (24, 48 and $72 \mathrm{~h}$ ) did not determine significant effects on DNA synthesis (data not shown). To demonstrate the involvement of ERs, we also investigated the effects of antiestrogens on H295R 
A

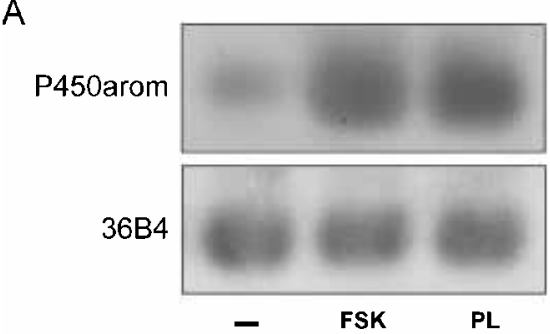

C

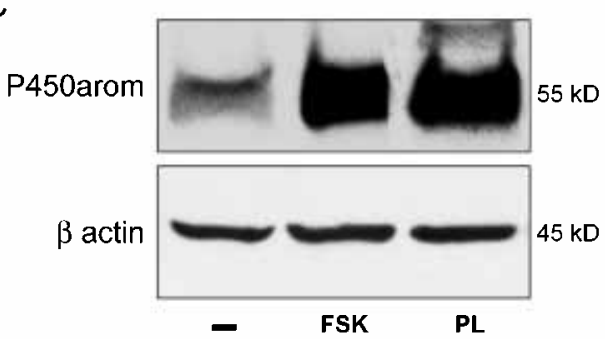

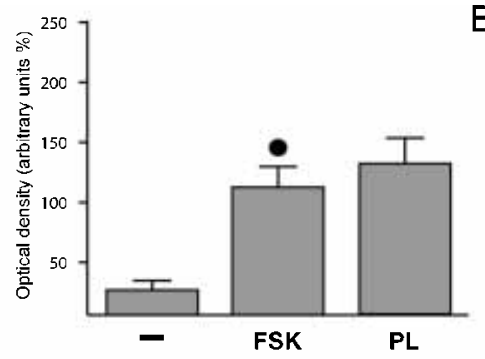

B

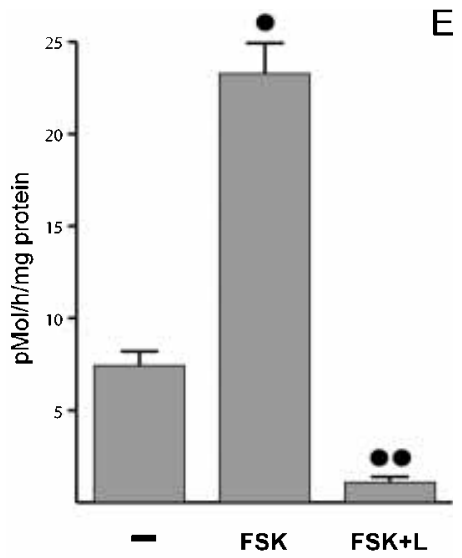

Figure 1 Effects of FSK on P450 aromatase expression and activity in cultured H295R cells. (A) P450 aromatase mRNA expression in H295R cells in the absence (-) or presence of FSK for $24 \mathrm{~h}$ was determined by semi-quantitative RT-PCR. Human placenta RNA (PL) was used as a positive control. 36B4 mRNA levels (lower panel) were also determined as a loading control. (B) Quantitative representation of data (means \pm S.E.M.) from three independent RT-PCR experiments after densitometry and correction for 36B4 expression. (C) Protein expression of P450 aromatase in H295R cells in the absence (-) or presence of FSK for $24 \mathrm{~h}$. Whole-cell extracts $(50 \mu \mathrm{g})$ were subjected to Western-blot analysis using anti-(human P450 aromatase) antibody (upper panel) and anti-actin antibody (lower panel) as a loading control. (D) Quantitative representation of data (means \pm S.E.M.) of three independent Western-blot experiments after densitometry and correction for $\beta$-actin expression. (E) Aromatase activity in H295R cells. The cells were cultured for $24 \mathrm{~h}$ in DMEM/F12 in the absence $(-)$ or presence of FSK $(25 \mu \mathrm{M})$, or FSK $(25 \mu \mathrm{M})$ combined with Letrozole $(4 \mu \mathrm{M} ; \mathrm{FSK}+\mathrm{L})$. Aromatase activity was assessed using the modified tritiated water method. The results obtained were expressed as pmol $\left[{ }^{3} \mathrm{H}\right]$ water released per $\mathrm{h}$ and were normalized for $\mathrm{mg}$ protein (pmol/h per mg protein). Values represent the means \pm S.E.M. from three different experiments, each performed with triplicate samples. $\bigcirc, P<0.01$ compared with untreated cells (-); O , $P<0.01$ compared with cells treated with FSK alone.

proliferation. Treatment with increasing amounts of ICI $(0 \cdot 1-10 \mu \mathrm{M})$ or OHT $(0 \cdot 1-10 \mu \mathrm{M})$ determined a dose-dependent inhibition of thymidine incorporation both under the basal conditions and in the presence of $\mathrm{E}_{2}(10 \mathrm{nM})$ (Fig. 3B). To further confirm that H295R growth depends on estrogens we investigated the effect of aromatase inhibitor Letrozole on cell proliferation. As shown in Fig. 3C treatment with increasing amounts of Letrozole $(1-10 \mu \mathrm{M})$ determined a dose-dependent inhibition of thymidine incorporation.

\section{Antiestrogens modulate ER $\beta$ expression}

The above results prompted us to evaluate whether ER $\beta$ expression can be modulated by $\mathrm{E}_{2}$ and/or antiestrogens such as ICI and OHT. Performing a semiquantitative RT-PCR we observed that a 24-h exposure to ICI or OHT was clearly able to up-regulate the mRNA levels of $\mathrm{ER} \beta$, which were not modified by $\mathrm{E}_{2}(10 \mathrm{nM})$ treatment (Fig. 4A and B). In fact, $\mathrm{E}_{2}$ dose-response $(0 \cdot 1-1000 \mathrm{nM})$ or time-course $(12,24$ and $48 \mathrm{~h})$ experiments did not reveal any significant differences with respect to controls (data not shown). Besides, Western-blot analysis revealed an increase in ER $\beta$ protein levels after a 96-h exposure to antiestrogens (Fig. 4C and D), which paralleled the evaluation of cell proliferation.

\section{Antiestrogens up-regulate FasL protein expression and induce activation of caspase pathway in H295R cells}

Microscopic observation of $\mathrm{H} 295 \mathrm{R}$ cells treated with $10 \mu \mathrm{M}$ OHT and stained with Hoechst 33342 showed morphological changes characteristic of apoptosis after only $24 \mathrm{~h}$ (Fig. 5). These changes were not observed in cells treated with estradiol or ICI (data not shown).

These results led us to ascertain the involvement of the Fas/FasL pathway in the OHT-promoted apoptosis of H295R cells. Fas protein was expressed but not modulated by $\mathrm{E}_{2}$, ICI or OHT in H295R cells (Fig. 6A and $\mathrm{D}$ ), however the expression of FasL was up-regulated only by OHT (Fig. 6B and E). The autocrine mechanism of apoptosis in H295R cells by the Fas/FasL system was further supported by the expression of the active forms of caspase-8 (p43/45 and p28) and caspase-3 (p20 and p17) induced only by OHT treatment (Fig. 7). 


\section{ER $\beta$ binds the activating protein (AP)-1 site on the FasL promoter}

Since for several ER-dependent genes transcription has been shown to be regulated through ER binding to the

A



B

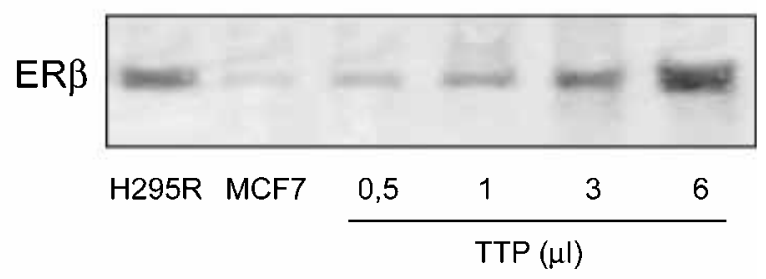

C

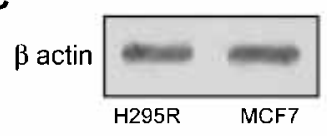

D



E

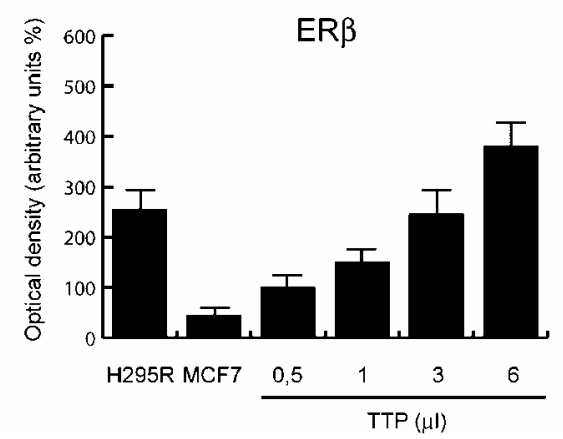

Journal of Molecular Endocrinology (2005) 35, 245-256
AP-1 complex, we used chromatin immunoprecipitation analysis to show ER $\beta$ binding to the AP- 1 site on the FasL promoter in H295R cells. Samples were immunoprecipitated with the ER $\beta$ antibody and the FasL promoter region containing the AP-1 site was amplified with specific primers. The results obtained show that $\operatorname{ER} \beta$ is able to interact with the protein complex bound to the AP- 1 site in basal conditions and that this binding is maintained in treated cells (Fig. 8). Bands are specific as shown by the lack of amplification in samples immunoprecipitated with nonimmune rabbit IgG.

\section{Discussion}

In the present study we have shown that H295R adrenocortical carcinoma cells are able to convert androgens to estrogens, which, through a short autocrine loop, mediated by their own receptors, contribute to enhance H295R cell proliferation. Furthermore, both antiestrogens ICI and OHT up-regulate ER $\beta$ expression and dose-dependently inhibit basal and $\mathrm{E}_{2}$-induced H295R cell proliferation by activating different pathways. In fact, whereas ICI determines the growth arrest of H295R cells, OHT treatment activates the Fas/FasL pathway which in turn induces apoptosis.

Androgens and estrogens determine various biological activities on mammalian tissues controlling cellular growth and differentiation through different signal transduction pathways. Previous studies have demonstrated that androgens inhibit H295R cell proliferation through the androgen receptor (Rossi et al. 1998), whereas the role of estrogens and ERs in both normal adult and malignant adrenocortical cells remains to be elucidated. Our results give a functional emphasis to recent studies which revealed that the H295R cell line is able to transform androgens into estrogens (Watanabe \& Nakaijn 2004) and express ER $\alpha$ and ER $\beta$ mRNA (Somjen et al. 2003). We demonstrated that high levels of basal aromatase activity are present in H295R cells, allowing these cells to produce $\mathrm{E}_{2}$. Moreover, H295R cells also express both ER protein isoforms, with a

Figure 2 Expression of ER $\alpha$ and $E R \beta$ in H295R cells. Western-blot analysis was performed on total proteins from $\mathrm{H} 295 \mathrm{R}$ or MCF-7 cells $(50 \mu \mathrm{g})$ and on in vitro-transcribed and -translated protein (TTP) ER $\alpha$ and ER $\beta$; (synthesized as described in the Materials and methods section) utilized as a standard curve at the indicated volumes. Anti-ER $\alpha(F 10)(A)$, anti-ER $\beta$ (B) and anti- $\beta$ actin (C) antibodies were used. These results are representative of those obtained in three independent experiments. ( $D$ and $E$ ) Quantitative represention of data (means \pm S.E.M.) from three independent Western-blot experiments performed after densitometry and correction for $\beta$-actin expression. For densitometric analysis, standard point with the lowest concentration was taken as $100 \%$ and band intesities were referred to the curve. 

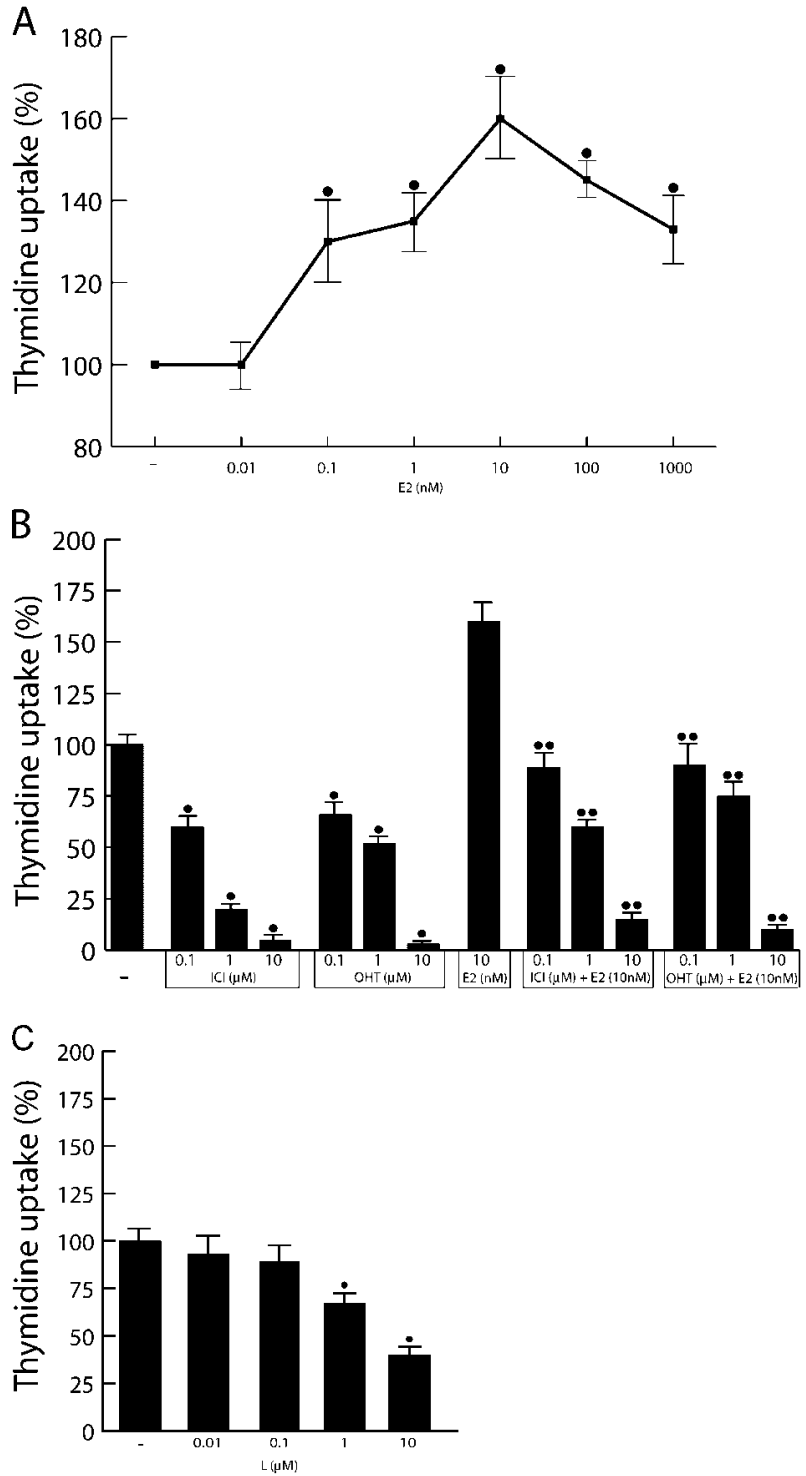

Figure 3 Proliferative analysis in H295R cells. Proliferation was evaluated by $\left[{ }^{3} \mathrm{H}\right]$ thymidine incorporation analysis. (A) H295R cells were cultured for $96 \mathrm{~h}$ in DMEM in the absence or presence of $E_{2}$ at the indicated concentrations. (B) H295R cells were cultured for $96 \mathrm{~h}$ in DMEM in the absence or presence of $\mathrm{E}_{2}, \mathrm{ICl}, \mathrm{OHT}, \mathrm{E}_{2}+\mathrm{ICl}$ or $\mathrm{E}_{2}+\mathrm{OHT}$ at the indicated concentrations. Control cells were treated with the same amount of vehicle alone (DMSO) that never exceeded $0.01 \%$ (v/v). (C) H295R cells were cultured for $96 \mathrm{~h}$ in DMEM in the absence or presence of Letrozole $(L)$ at the indicated concentrations. Values expressed as percentages of untreated cells $(100 \%)$; means \pm S.E.M. from three independent experiments each performed with triplicate samples. . $P<0.01$ compared with untreated cells $(-) ; 0$, $P<0.01$ compared with $\mathrm{E}_{2}$-treated cells $\left(\mathrm{E}_{2}\right)$.

prevalence of $\mathrm{ER} \beta$, thus reproducing the same $\mathrm{ER}$ ratio present in the fetal adrenal gland (Takeyama et al. 2001). The exposure to a physiological concentration of $\mathrm{E}_{2}$ determined a slight but significant increase of thymidine incorporation, confirming the results of a previous study (Somjen et al. 2003) and revealing the presence of an autocrine mechanism which could contribute to H295R cell proliferation. The observation that both antiestrogens and the aromatase inhibitor Letrozole determined a dose-dependent arrest of these proliferative effects supports this hypothesis. However, only OHT was responsible for the morphological changes associated with apoptosis as observed in previous studies performed on MCF-7 breast cancer cells using tamoxifen and its analogs (Bardon et al. 1987, Warri et al. 1993, Wilson et al. 1995). On the contrary, apoptotic events were shown to be induced also by ICI in ER-positive primary breast cancer cells (Ellis et al. 1997). Moreover a study performed on six malignant rhabdoid tumor cell lines revealed that OHT but not ICI induced apoptosis (Koshida et al. 2002). To explain these apparently controversial data we have to take into account that the pharmacological potency elicited by antiestrogens is dependent on the cellular context as well as on the interaction of these molecules with the two different ER isoforms. This hypothesis is supported by studies which have shown that ER agonists and antagonists are able to induce distinct conformations and biological activity of both ER isoforms (Van Den Bemd et al. 1999). A study using a fingerprint assay clearly indicates that OHT determines, for both ER $\alpha$ and ER $\beta$, the exposure of unique peptide-binding surfaces that are not exposed in the presence of ICI (Paige et al. 1999). So, different ER-ligand complexes may be able to recruit different coactivator and corepressor proteins within the cell, and the overall biological response is determined by unique combinations of protein-protein interactions that occur in a given cell and promoter context (Jones et al. 1999). The present study contributes to the understanding of the biological activity of OHT and ICI, extending to adrenocortical cancer cells the different response to antiestrogens.

We ascertained that the antiestrogens OHT and ICI were able to induce the up-regulation of $\mathrm{ER} \beta$, whereas $\mathrm{E}_{2}$ did not show any change in our experimental conditions. What is the molecular mechanism by which antiestrogens can enhance ER $\beta$ expression and what is the biological counterpart of this response? It is worth noting that Paech et al. (1997) reported an antiestrogendependent transcriptional activity of $\mathrm{ER} \beta$ at AP-1 sites which were demonstrated to be located within the promoter region of $\mathrm{ER} \beta$ gene (Li et al. 2000). In line with these findings, our data may provide new insight on ER $\beta$ autologous regulation by antiestrogens as displayed even in H295R cells. Moreover, could this up-regulation of ER $\beta$ mediate the above reported down-regulatory effects of ICI and OHT on H295R cell proliferation? This question opens an additional intriguing area of research that we are investigating currently. 
A



C



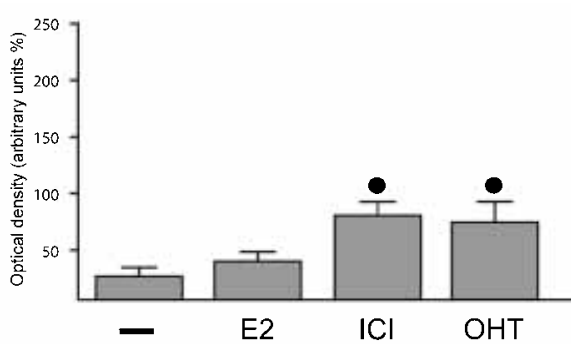



Figure 4 Effects of antiestrogens on ER $\beta$ expression in H295R cells. (A) ER $\beta$ mRNA expression in H295R cells in the absence $(-)$ or presence of $E_{2}(10 \mathrm{nM}), \mathrm{ICl}(10 \mu \mathrm{M})$ or OHT $(10 \mu \mathrm{M})$ for $24 \mathrm{~h}$ was determined by semi-quantitative RT-PCR (upper panel). 36B4 mRNA levels (lower panel) were used as a loading control. (B) Quantitative representation of data (means \pm S.E.M.) from three independent RT-PCR experiments after densitometry and correction for 36B4 expression. (C) ER $\beta$ protein expression in H295R cells in the absence or presence of $E_{2}(10 \mathrm{nM}), \mathrm{ICI}(10 \mu \mathrm{M})$ or OHT $(10 \mu \mathrm{M})$ for $96 \mathrm{~h}$ was determined by Western blotting (upper panel); $\beta$-actin was also used as a loading control (lower panel). (D) Quantitative representation of data (means \pm S.E.M.) of three independent Western-blot experiments after densitometry and correction for $\beta$-actin expression. $P, P<0.01$ compared with untreated cells $(-)$.

In H295R cells we also observed that ICI determined a dose-dependent inhibition of proliferation. This cytostatic effect could be explained by the inhibitory effects exerted by ICI on the IGF signaling pathway, which is activated strongly in H295R cells by the autocrine action of IGF-II through the type 1 IGF receptor (IGF-1R; Logié et al. 1999). In fact, in mammary tissue it has been demonstrated that the effect of estrogen on cell growth is mediated by the up-regulation of IGF-1R (Stewart et al. 1990), insulin receptor substrate (IRS)-1 and IRS-2 (Lee et al. 1999) expression and/or by the down-regulation of the inhibitory IGF-binding protein 3 (IGFBP-3; Huynh et al. 1996), while ICI reduced basal phosphorylation of IGF-1R, IRS-1, IRS-2, Akt-1 and the p85 subunit of phosphoinositide 3-kinase (Chan et al. 2001). These observations indicate that inhibition of cell growth by ICI may not only be attributable to competition between estrogens and ICI for ER but also to the interruption of the IGF signaling pathway. By doing so, ICI may also block a possible cross-talk between the ER and IGF-1R signaling pathways (Dupont et al. 2000). The molecular mechanism determining the cytostatic effect of ICI on H295R cells is currently under investigation, but preliminary results seem to confirm this hypothesis.

Interestingly, we demonstrated the involvement of the Fas/FasL system as a signal transduction pathway mediating the OHT-induced apoptosis. FasL is a membrane protein belonging to the tumor necrosis factor family (Suda et al. 1993), which is able to induce apoptosis by cross-linking with the Fas receptor (Takahashi et al. 1994). FasL is normally expressed on activated cells of the immune system and is used for killing cells infected with viruses or cancer cells expressing Fas (Suda et al. 1993). It has also been demonstrated that tumor cells can express FasL by which they kill Fas-positive immune cells evading the immune system (Walker et al. 1997, Nagarkatti 2000). Recently, it has been described that, in certain Fas-positive tumor cells, OHT induces apoptotic effects by up-regulating FasL (Nagarkatti \& Davis 2003). Our study recalls these observations since we have shown that H295R cells are Fas-positive and that OHT is able to increase the expression of FasL which may activate pro-apoptotic events. This autocrine mechanism is further substantiated by the cleavage of caspase- 8 and caspase-3 observed upon OHT treatment. Notably, 
A

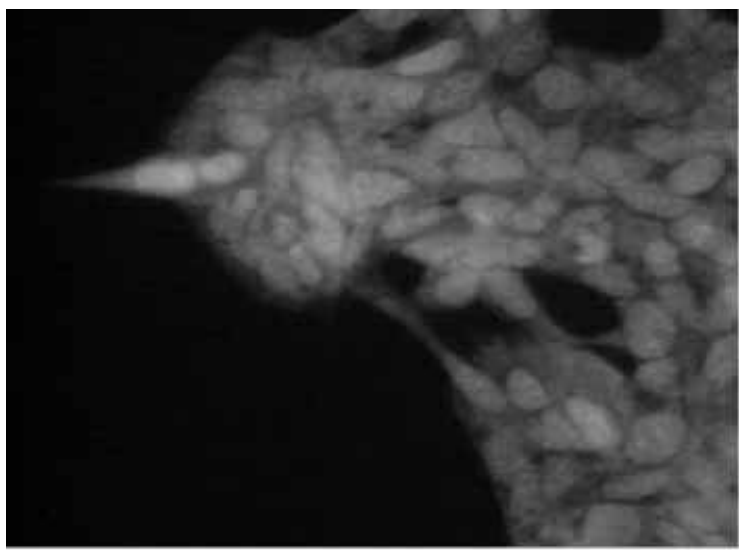

B



Figure 5 Induction of apoptosis in H295R cells by OHT. H295 cells were cultured for $24 \mathrm{~h}$ in the absence $(A)$ or presence (B) of $10 \mu \mathrm{M} \mathrm{OHT}$. Control cells were treated with the same amount of vehicle alone (DMSO) that never exceeded $0.01 \%$ (v/v). The cells were stained subsequently with Hoechst 33342 . These results are representative of those obtained in three independent experiments.

these phenomena could be consequent to the interaction of the ER $\beta$-OHT complex with the promoter of FasL, which contains a complete AP-1 sequence (Mor et al. 2000), while in our cellular context the ER $\beta$-ICI complex seems to be unable to activate FasL transcription.

A previous study (Mor et al. 2000) reported that OHT inhibits the expression of FasL in MCF-7 and in T47D breast tumor cells through ER $\alpha$. In contrast, other authors showed that OHT is able to up-regulate FasL in T47D cells (Nagarkatti \& Davis 2003), depending on the concentrations of treatments and culture conditions. A role for $E R \beta$ in the regulation of FasL has been hypothesized by a study on neuronal cells demonstrating that $\mathrm{ER} \beta$ mediates apoptosis induction in cells expressing Fas/FasL proteins, while ER $\alpha$ has antiapoptotic and neuroprotective effects (Nilsen et al. 2000). Mechanisms controlling the activation of ER-dependent
A



B

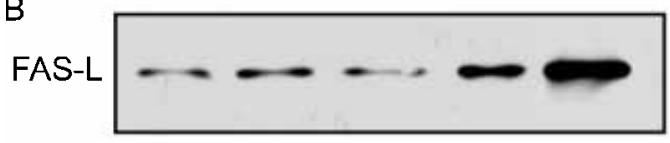

C

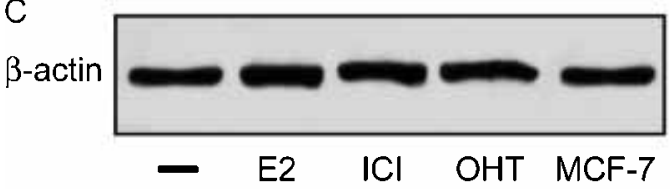

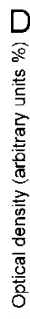
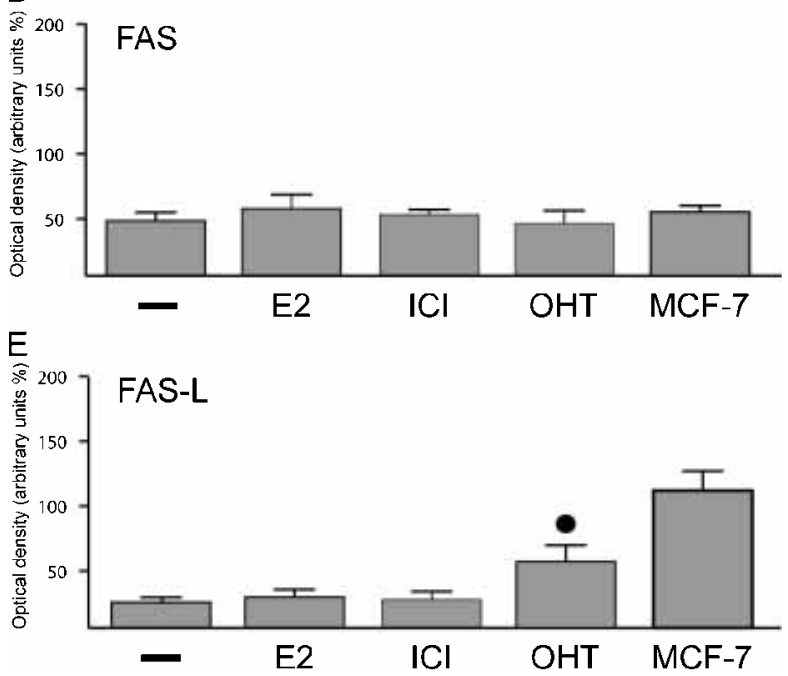

Figure 6 Expression of Fas and FasL in H295R cells. Western blots of Fas (A) and FasL (B) on H295R whole-cell extracts $(50 \mu \mathrm{g})$ after $24 \mathrm{~h}$ of treatment with $\mathrm{E}_{2}(10 \mathrm{nM}), \mathrm{ICl}(10 \mu \mathrm{M})$ or $\mathrm{OHT}(10 \mu \mathrm{M})$. (C) $\beta$-Actin was used as a loading control. (D) Quantitative representation of data (means \pm S.E.M.) from three independent Western-blot experiments using antibody anti-Fas after densitometry and correction for $\beta$-actin expression. (E) Quantitative representation of data (means \pm S.E.M.) from three independent Western-blot experiments using antibody anti-FasL after densitometry and correction for $\beta$-actin expression. MCF-7 whole cell extracts were used as positive controls. $P<0.01$ compared with untreated cells $(-)$.

genes through AP-1 sites are not completely clear. ER $\beta$ shows a unique capacity to enhance AP-1 activity in response to selective antiestrogens (Paech et al. 1997, Weatherman \& Scanlan 2001); this is due to ER $\beta$ interactions with corepressors, as such interactions are inhibited by antiestrogens and increased by agonists (Webb et al. 2003, Uht et al. 2004). Our data show that $\mathrm{ER} \beta$ is able to interact with the proteins bound to the 



$\beta$-actin

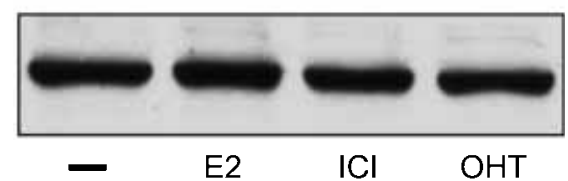

Figure 7 OHT induces caspase-8 and caspase-3 activation in $\mathrm{H} 295 \mathrm{R}$ cells. The effect of $\mathrm{E}_{2}(10 \mathrm{nM}), \mathrm{ICl}(10 \mu \mathrm{M})$ or OHT $(10 \mu \mathrm{M})$ on caspase-8 and caspase-3 activation was evaluated by Western-blot analysis. Active forms of caspase-8 (p43/45 and p28; upper panel) and caspase-3 (p20 and p17; middle panel) were revealed only after OHT treatment for $24 \mathrm{~h}$; $\beta$-actin was used as a loading control (lower panel). These results are representative of those obtained in three independent experiments.

AP-1 complex on human FasL promoter and confirm that transcriptional activity does not depend only on $\mathrm{ER} \beta$ binding to the promoter but instead depends on ER $\beta$ 's ability to recruit specific cofactors. In our cellular context, the interaction between ER $\beta$ and OHT may be able to recruit corepressors bound to the AP-1 complex determining the activation of FasL expression that in turn promotes apoptosis. Nevertheless we cannot exclude that high doses of OHT are also able to induce apoptosis involving other factors such as p53 or c-Myc in a direct manner (Mandlekar \& Kong 2001). Whatever the mechanism involved, what clearly emerges from this study is that the H295R adrenocortical cancer cell line exhibits estrogen-sensitive proliferation which can be inhibited by exposure to antiestrogens ICI and OHT or the aromatase inhibitor Letrozole. The present findings and our preliminary observations (Barzon et al., unpublished observations), which clearly reveal (by real-time PCR and western-blot analysis) the expression of ER $\beta$ in human adrenocortical carcinoma tissues, open new perspectives on the potential therapeutic benefits of antiestrogens as pharmacological agents in antagonizing adrenocortical carcinoma cell growth and progression. However, further studies are needed to clarify the role for ER $\beta$ as a possible mediator of adrenocortical cell proliferation.
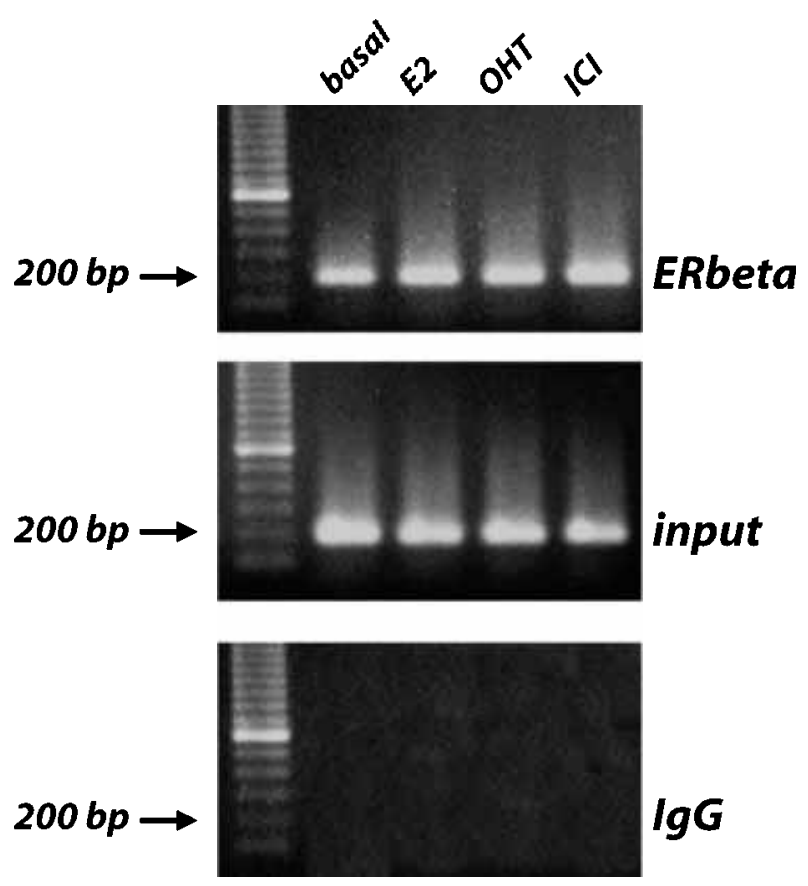

Figure $8 \mathrm{ER} \beta$ is recruited to the FasL promoter. H295R cells were incubated for $24 \mathrm{~h}$ with E2 $(10 \mathrm{nM})$, OHT $(10 \mu \mathrm{M})$ or $\mathrm{ICl}$ $(10 \mu \mathrm{M})$. Control cells were treated with the same amount of vehicle alone (DMSO) that never exceeded $0.01 \%(\mathrm{v} / \mathrm{v})$. In vivo binding of ER $\beta$ to the FasL promoter was examined using ChIP assay. Immunoprecipitated (ER $\beta$, IgG) and total (10\% input) DNA were subject to PCR using specific primers. These results are representative of those obtained in three independent experiments.

\section{Acknowledgements}

We thank Astra-Zeneca Italia for providing us with ICI 182,780 and Novartis Pharma AG (Basel, Switzerland) for providing us with Letrozole. This work was supported by MIUR (ex 60\%) (Italy). The authors declare that there is no conflict of interest that would prejudice the impartiality of this scientific work.

\section{References}

Albrecht ED, Babischkin JS, Davies WA, Leavitt MG \& Pepe GJ 1999 Identification and developmental expression of the estrogen receptor alpha and beta in the baboon fetal adrenal gland. Endocrinology 140 5953-5961.

Andrews NC \& Faller DV 1991 A rapid micropreparation technique for extraction of DNA-binding proteins from limiting numbers of mammalian cells. Nucleic Acids Research 192499.

Bardon S, Vignon F, Montcourrier P \& Rochefort H 1987 Steroid receptor-mediated cytotoxicity of an antiestrogen and an antiprogestin in breast cancer cells. Cancer Research 47 1441-1448.

Barzon L, Chilosi M, Fallo F, Martignoni G, Montagna L, Palu G \& Boscaro M 2001 Molecular analysis of CDKN1C and TP53 in sporadic adrenal tumors. European Fournal of Endocrinology 145 207-212. 
Barzon L, Sonino N, Fallo F, Palu G \& Boscaro M 2003 Prevalence and natural history of adrenal incidentalomas. European Fournal of Endocrinology 149 273-285.

Bourcigaux N, Gaston V, Logié A, Bertagna X, Le Bouc Y \& Gicquel C 2000 High expression of cyclin E and G1 CDK and loss of function of p57 KIP2 are involved in proliferation of malignant sporadic adrenocortical tumors. Fournal of Clinical Endocrinology and Metabolism 85 322-330.

Bradford MM 1976 A rapid and sensitive method for the quantitation of microgram quantities of protein utilizing the principle of protein-dye binding. Analytical Biochemistry 72 248-254.

Chan TW, Pollak M \& Huyunh H 2001 Inhibition of insulin-like growth factor signaling pathways in mammary gland by pure antiestrogen ICI 182,780. Clinical Cancer Research 7 2545-2554.

Dupont J, Karas M \& LeRoith D 2000 The potentiation of estrogen on insulin-like growth factor I action in MCF-7 human breast cancer cells includes cell cycle components. Fournal of Biological Chemistry 275 35893-35901.

Ellis PA, Saccani-Jotti G, Clarke R, Johnston SRD, Anderson E, Howell A, A'Hern R, Salter J, Detre S, Nicholson R et al. 1997 Induction of apoptosis by tamoxifen and ICI 182780 in primary breast cancer. International Fournal of Cancer 72 608-613.

Gao X, Loggie BW \& Nawaz Z 2002 The roles of sex steroid receptor coregulators in cancer. Molecular Cancer 17.

Gazdar AF, Oie HK, Shackleton CH, Chen TR, Triche TJ, Myers CE, Chrousos GP, Brennan MF, Stein CA \& La Rocca RV 1990 Establishment and characterization of a human adrenocortical carcinoma cell line that expresses multiple pathways of steroid biosynthesis. Cancer Research 50 5488-5496.

Gicquel C, Raffin-Sanson M, Gaston V, Bertagna X, Plouin P, Schlumberger M, Louvel A, Luton J \& Le Bouc Y 1997 Structural and functional abnormalities at $11 \mathrm{p} 15$ are associated with the malignant phenotype in sporadic adrenocortical tumors. Study on a series of 82 tumors. Fournal of Clinical Endocrinology and Metabolism 87 2559-2565.

Hamelers IHL \& Steenbergh PH 2003 Interactions between estrogen and insulin-like growth factor signaling pathways in human breast tumor cells. Endocrine-related Cancer 10 331-345.

Hirst JJ, West NB, Brenner RM \& Novy MJ 1992 Steroid hormone receptors in the adrenal glands of fetal and adult rhesus monkeys. Fournal of Clinical Endocrinology and Metabolism 75 308-314.

Hsing AW, Nam JM, Co Chien HT, McLaughlin JK \& Fraumeni Jr JF 1996 Risk factors for adrenal cancer: an exploratory study. International Fournal of Cancer 65 432-436.

Huynh H, Yang X \& Pollak M 1996 Estradiol and antiestrogens regulate a growth inhibitory insulin-like growth factor binding protein 3 autocrine loop in human breast cancer cells. Fournal of Biological Chemistry 271 1016-1021.

Jones PS, Parrott E \& White IN 1999 Activation of trascription by estrogen receptor alpha and beta is cell type- and promoterdependent. Fournal of Biological Chemistry 274 32008-32014.

Kirschner LS 2002 Signaling pathways in adrenocortical cancer. Annals of the New York Academy of Sciences 968 222-239.

Koshida S, Narita Tsutomu, Kato H, Yoshida S, Taga T, Ohta S \& Takeuchi Y 2002 Estrogen receptor expression and estrogen receptor-independent cytotoxic effects of tamoxifen on malignant rhabdoid tumor cells in vitro. Fapanese Fournal of Cancer Research 93 $1351-1357$.

Lee AV, Jackson JG, Gooch JL, Hilsenbeck SG, Coronado-Heinsohn E, Osborne CK \& Yee D 1999 Enhancement of insulin-like growth factor signaling in human breast cancer: estrogen regulation of insulin receptor substrate-1 expression in vitro and in vivo. Molecular Endocrinology 13 787-796.

Lephart ED \& Simpson ER 1991 Assay of aromatase activity. Methods in Enzymology 206 477-483.

Li LG, Yeh CG, Nojima D \& Dahiya R 2000 Cloning and caracterization of human estrogen receptor $\beta$ promoter. Biochemistry and Biophysics Research Communications 275 682-689.
Logié A, Boulle N, Gaston V, Perin L, Boudou P, Le Bouc Y \& Gicquel C 1999 Autocrine role of IGF-II in proliferation of human adrenocortical carcinoma NCI H295R cell line. Fournal of Molecular Endocrinology 23 23-32.

Maggiolini M, Donzè O \& Picard D 1999 A non-radioactive method for inexpensive quantitative RT-PCR. Biological Chemistry $\mathbf{3 8 0}$ 695-697.

Mandlekar S \& Kong AN 2001 Mechanisms of tamoxifen-induced apoptosis. Apoptosis 6 469-477.

Mor G, Kohen F, Garcia-Velasco J, Nilsen J, Brown W, Song J \& Naftolin F 2000 Regulation of Fas ligand expression in breast cancer cells by estrogen: functional differences between estradiol and tamoxifen. Fournal of Steroid Biochemistry and Molecular Biology 73 185-194.

Nagarkatti N 2000 Tumor-derived FasL induces toxicity in lymphoid organs and plays an important role in successful chemotherapy. Cancer Immunology and Immunotherapy 49 46-55.

Nagarkatti N \& Davis BA 2003 Tamoxifen induces apoptosis in Fas + tumor cells by upregulating the expression of Fas ligand. Cancer Chemotherapy and Pharmacology 51 284-290.

Nilsen J, Mor G \& Naftolin F 2000 Estrogen-regulated developmental neuronal apoptosis is determined by estrogen receptor subtype and the Fas/Fas ligand system. Foumal of Neurobiology 43 64-78.

Nilsson S, Makela S, Treuter E, Tujague M, Thomsen J, Andersson G, Enmark E, Pettersson K, Warner M \& Gustafsson JA 2001 Mechanisms of estrogen action. Physiology Reviewes 81 1535-1565.

Paech K, Webb P, Kuiper GGJM, Nilsson S, Gustafsson JA, Kushner PJ \& Scanlan TS 1997 Differential ligand activation of estrogen receptor ER $\alpha$ and ER $\beta$ at AP1 sites. Science $\mathbf{2 7 7}$ 1508-1510.

Paige LA, Christensen DJ, Gron H, Norris JD, Gottlin EB, Padilla KM, Chang CY, Ballas LM, Hamilton PT, McDonnell DP \& Fowlkes DM 1999 Estrogen receptor (ER) modulators each induce distinct conformational changes in ER alpha and ER beta. PNAS 96 3999-4004.

Rainey WE, Bird IM \& Mason JI 1994 The NCI-H295 cell line: a pluripotent model for human adrenocortical studies. Molecular and Cellular Endocrinology 100 45-50.

Rossi R, Zatelli MC, Valentini A, Cavazzini P, Fallo F, del Senno L \& degli Uberti EG 1998 Evidence for androgen receptor gene expression and growth inhibitory effect of dihydrotestosterone on human adrenocortical cells. Fournal of Endocrinology 159 373-380.

Somjen D, Stern N, Knoll E, Sharon O, Gayer B, Kulik T \& Kohen F 2003 Carboxy derivatives of isoflavones as affinity carriers for cytotoxic drug targeting in adrenocortical H295R carcinoma cells. Fournal of Endocrinology 179 395-403.

Stewart AJ, Johnson MD, May FE \& Westley BR 1990 Role of insulin-like growth factors and the type I insulin-like growth factor receptor in the estrogen-stimulated proliferation of human breast cancer cells. Fournal of Biological Chemistry 265 21172-21178.

Suda T, Takahashi T, Golstein P \& Nagata S 1993 Molecular cloning and expression of the Fas ligand, a novel member of the tumor necrosis factor family. Cell $\mathbf{7 5}$ 1169-1178.

Takahashi T, Tanaka M, Brannan CI, Jenkins NA, Copeland NG, Suda T \& Nagata S 1994 Generalized lymphoproliferative disease in mice, caused by a point mutation in the Fas ligand. Cell 76 969-976

Takeyama J, Suzuki T, Inoue S, Kaneko C, Nagura H, Harada N \& Sasano H 2001 Expression and cellular localization of estrogen receptors alpha and beta in the human fetus. Fournal of Clinical Endocrinology and Metabolism 86 2258-2262.

Uht RM, Webb P, Nguyen P, Price Jr RH, Valentine C, Favre H \& Kushner PJ 2004 A conserved lysine in the estrogen receptor DNA binding domain regulates ligand activation profiles at AP-1 sites, possibly by controlling interactions with a modulating repressor. Nuclear Receptor 22. 
Van Den Bemd JG, Kuiper GG, Pols HA \& Van Leeuwen JP 1999 Distinct effects on the conformation of estrogen receptor alpha and beta by both the antiestrogens ICI 164,384 and ICI 182,780 leading to opposite effects on receptor stability. Biochemistry and Biophysics Research Communications 261 1-5.

Walker PR, Saas P \& Dietrich PY 1997 Role of Fas ligand (CD95 L) in immune escape: the tumor cell strikes back. Fournal of Immunology 158 4521-4524.

Warri AM, Huovinen RL, Laine AM, Martikainen PM \& Harkonen K 1993 Apoptosis in toremifene-induced growth inhibition of human breast cancer cells in vivo and in vitro. Fournal of the National Cancer Institute 85 1412-1418.

Watanabe M \& Nakaijn S 2004 Forskolin up-regulates aromatase (CYP19) activity and gene transcripts in the human adrenocortical carcinoma cell line H295R. Fournal of Endocrinology 180 125-133

Weatherman RV \& Scanlan TS 2001 Unique protein determinants of the subtype-selective ligand responses of the estrogen receptors
(ERalpha and ERbeta) at AP-1 sites. Fournal of Biological Chemistry 276 3827-3832.

Webb P, Valentine C, Nguyen P, Price Jr RH, Marimuthu A, West BL, Baxter JD \& Kushner PJ 2003 ERbeta binds N-CoR in the presence of estrogens via an LXXLL-like motif in the N-CoR G-terminus. Nuclear Receptor 14.

Weber MM, Fottner C \& Wolf E 2000 The role of the insulin-like growth factor system in adrenocortical tumourigenesis. European Fournal of Clinical Investigation 30 69-75.

Wilson JW, Wakeling AE, Morris ID, Hickman JA \& Dive C 1995 MCF-7 human mammary adenocarcinoma cell death in vitro in response to hormone-withdrawal and DNA damage. International Journal of Cancer $\mathbf{6 1} 502-508$.

Received 25 May 2005

Accepted 14 June 2005

Made available online as an Accepted Preprint 23 June 2005 